\title{
Who benefits from share splits?
}

\author{
T.A. Cross and C. Firer \\ Graduate School of Business Administration, University of the Witwatersrand, Johannesburg
}

The objective of this study was to carry out an investigation into the excess return behaviour of companies on the Johannesburg Stock Exchange which split their shares in the period $1972-1984$. The concept of an event study was used in the analysis. Positive average residuals were observed in the months leading up to the split. In the month of the split large average excess returns were displayed. However, no long-term favourable effects on share price were found. Splits appeared to be a reaction to a sustained period of above-average returns rather than the cause of such returns. The splitting of a company's shares does not appear to influence the share's rand value traded. S. Afr. J. Bus. Mgmt. 1986, 17: $87-92$

Die doel van hierdie studie was om navorsing te doen op die oormatige winsoplewerings van maatskappye wat op die Johannesburgse Effektebeurs verskyn en waarvan die aandele verdeeld was in die periode $1972-1984$. Die konsep van 'n gevallestudie is in die ontleding gebruik. Positiewe oorskotte is gevind in die maande wat die verdeling voorafgegaan het. In die maand van die verdeling is groot winste vertoon, maar geen gunstige langtermynuitwerkings op aandeelpryse het voorgekom nie. Verdelings is skynbaar eerder 'n reaksie op 'n volgehoue periode van bogemiddelde winste as die oorsaak van dié winste. Dit lyk asof die verdeling van 'n maatskappy se aandele geen invloed het op die randwaarde waarvoor die aandele op die effektebeurs verhandel word nie.

S.Afr. Tydskr. Bedryfsl. 1986, 17: $87-92$

\section{Introduction}

Research into one specific area of the capital structure decision has been relatively neglected in South Africa, namely the purpose and effects of share splits. The popular financial press has periodically carried reports discussing the benefits to be obtained, especially by small individual investors, from the splitting of 'high priced' shares. These reports often exhort companies with 'high' share prices to split their shares in the interests of the shareholding public. They usually imply that splitting would not only reduce trading costs but would also assist in achieving a primary goal of management, namely, the maximization of long-term shareholder wealth.

A share split, unlike most dividend or capital structure decisions, does not have any direct effect on the future cash flows of the firm. It merely results in an increase in the number of shares issued, accompanied by a proportional decrease in the par value of the shares, leaving the book value of shareholders' funds unchanged.

A split thus appears to be '. . no more than a cosmetic accounting change with no direct cost benefit' (Grinblatt, Masulis \& Titman, 1984).

If this is indeed the case, why then do companies indulge in the expensive pastime of splitting their shares? This study seeks empirical evidence which will go some small way towards providing the answer to this conundrum.

\section{Prior research}

Research on share splits in the USA, which dates back as far as the 1930s, has been carried out in three main areas.

\section{The effect of share splits on share prices}

Early research established that splits were associated with increasing share prices, and it was thought that the splits were in fact the cause of the price increases. Barker (1956) noted a close association between splits and dividend increases and concluded that the divided increases were in fact the fundamental cause of the share price increases, rather than the share split event.

Fama, Fisher, Jensen \& Roll (1969), using an event study, examined the share price movements around the split dates for all 940 share splits that took place on the New York Stock Exchange from 1927 to 1959.

They calculated cumulative average residuals (CAR's) from the market model, using monthly data. They found that the graph of the CAR's increased continuously from month -29 until the split month, but no such abnormal returns were found thereafter.

The incidence of share splits tended to be largely cyclical,
T.A. Cross and C. Firer*

Graduate School of Business Administration, University of the Witwatersrand, P.O. Box 31170, Braamfontein, 2017 Republic of South Africa

*To whom correspondence should be addressed 
with most splits having taken place during or towards the end of 'bull-market' conditions during which general increases in share prices had been observed.

Whilst above-normal returns preceded the share splits, it seemed unlikely that those returns had much to do with the actual split event, because the abnormal returns commenced about 30 months prior to the split date. This seemed to indicate that it was not the split event itself which caused increased returns, but rather a selection bias was operative, namely, that shares split because their price had increased up to the split date.

Fama, et al. (1969) thought that splits may be interpreted by investors as providing information about changes in the firms' future cash flows. They tested this hypothesis by segmenting the sample into those firms which increased their dividends beyond the average in the market after the split, and those which produced lower than average dividends.

They concluded that any price increases associated with splits were not caused by the splits themselves, but rather by investor expectations that share splits would be associated with dividend increases. The split event was therefore found to have informational content about other changes, rather than any of its own direct consequences. They found no long-run financial advantages identified for shareholders as a result of share splits.

They also concluded that, without insider information ahead of the split announcement, there was no way to use a split to increase expected returns. In a more recent study, Reilly \& Drzycimski (1981) also found that, except for investors with early insider information, there were also no short-term price benefits to shareholders.

\section{The effect of share splits on trading liquidity}

Because an optimal price range was thought to stimulate trading volumes, the trading volume implications of share splits were also researched.

As with the research on share price effects, the findings of a study by Copeland (1979) ran contrary to popular expectations. He found that after a split, proportionally lower trading volumes, but higher brokerage costs and bid-ask spreads were observed, pointing to reduced liquidity. These results contradicted the commonly held belief that splits improve trading liquidity and thereby ultimately help to increase the share price.

In a more recent study, Murray (1985) examined the longer term effects of splits and found no significant changes in liquidity or bid-asked spreads.

\section{Attitudes towards share splits}

Despite there being no sound theoretical reason nor any convincing empirical evidence that share splits are beneficial to shareholders, a popular myth persists about the positive effect of splits. The myth is usually supported by anecdotal observations relating to price increases in splitting shares. The price increases are ascribed largely to the lowering of the share price (via a split) into an 'optimal price range'. This 'optimal price range' is thought to attract small investors, increase the total number of shareholders, and thereby increase trading volumes, liquidity and consequently the share price.

The principal cause of the myth seems to be the failure to recognize that splits have not caused price rises, but rather that prices have usually been rising rapidly for many months prior to a split. Split events were more likely a response to sustained price rises, with the splits designed to adjust prices back to the 'optimal range'.
In 1980, the New York Stock Exchange surveyed the attitudes towards share splits of chief financial of ficers of NYSE. listed companies, individual investors and institutional in vestors. The following were the main findings.

Three quarters of individual investors believed that a split offered an investment opportunity. A third had considered making a purchase simply because the share had split. These attitudes appeared through all divisions of income, age, sex, and prior experience with split shares.

Individual investor attitudes toward share splits appeared to be overwhelmingly positive and companies reported satisfaction with their share split results. It therefore seems that share split decisions may be taken with a view to satisfying this sector of the investing community.

Unlike individual investors, institutional portfolio managers and traders attached little importance to stock splits in their investment decisions and considered them a 'non-event'. Any company splitting its shares in an attempt to improve its institutional investor image is almost certain to be wasting time and shareholders' money.

Practically all companies said they split to bring the share price to a more 'popular' level. Some aimed to increase trading volumes or the number of shareholders, whereas others sought to broaden the geographic distribution of their shareholders. A 'high' share price was almost always a prerequisite for splitting. Of the corporate respondents $92 \%$ believed that the results achieved warranted the costs of the share split, and $96 \%$ were willing to consider future splits.

Only those companies with a large percentage of small investors should therefore seriously consider a split. If their major shareholders are mainly institutions, they will gain little from a split unless they hope to attract more small investors. Such action could possibly antagonize the existing institutional investors who may perceive the split as a waste of money.

\section{Objectives}

Because of the persistence of myths surrounding the splitting of shares and despite the evidence thus far accumulated overseas, it was felt that a study of splits on the Johannesburg Stock Exchange (JSE) would help to clarify the local situation. An empirical investigation was therefore conducted into the investment returns associated with JSE-listed shares which split during the period 1972-1984.

\section{Methodology}

\section{Event studies}

When investigating the behaviour of share prices around the time of an occurrence such as a share split, instead of studying a single split event, it is usual to combine a large number of similar events (Bowman, 1983). In such studies, the events of interest occur over a variety of calendar times. They are therefore subject to a distribution of non-specific and noncontemporaneous influences. The reason for the aggregation of sample data in this way is that a more robust study, less subject to the problem of experimental error, is obtained, because the distribution of influences, being non-systematic in nature, will tend to be off-setting.

The event being studied here is the splitting of a company's shares. The companies in the sample all split their shares at different times between 1972 and 1984. Irrespective of split date, the month in wich a company splits its shares is designated month 0 in event time; the month before the split is month -1 , etc. All other times are thus described in event time relative to the zero time when the event being studied occurred. 
In order to achieve the aggregation, all data pertaining to each event month are simply summed over the companies in the sample.

\section{Sample selection}

The share splits chosen for inclusion in the study were identified from Johannesburg Stock Exchange Monthly Bulletins. Only ordinary shares which split during the period 1972-1984 were included in the sample, and any sub-divisions accompanied by other simultaneous or near-simultaneous restructuring such as rights issues, capitalization issues or consolidations were excluded to reduce the effects of confounding events. Two splits had to be excluded because of the extremely low trading which occurred in the shares. The final sample contained 34 shares which are listed in Table 1 in chronological order of occurrence of their share splits.

The data used in the analysis comprised month-end share prices, dividend amounts and ex-dividend dates, the monthly JSE actuaries all share index and its dividend yield.

Table 1 Final sample of 34 split shares

\begin{tabular}{rlr}
\hline \multicolumn{1}{c}{ Date } & Name & Ratio \\
\hline $7 / 72$ & Pioneer Holdings & $5: 1$ \\
$1 / 73$ & Plascon Evans & $5: 1$ \\
$8 / 73$ & James Brown \& Hamer & $2: 1$ \\
$10 / 73$ & Sasbank & $4: 1$ \\
$11 / 73$ & Edworks & $5: 1$ \\
$1 / 74$ & Amalgamated Industrial Inv. & $4: 1$ \\
$3 / 74$ & Murray \& Roberts & $2: 1$ \\
$3 / 74$ & Stein Brothers & $4: 1$ \\
$7 / 74$ & Russell Holdings & $5: 1$ \\
$7 / 74$ & Steel \& Barnett & $2: 1$ \\
$1 / 76$ & Vereeniging Estates & $4: 1$ \\
$6 / 77$ & Griqualand Exploration & $5: 1$ \\
$3 / 78$ & Otis Elevators & $5: 1$ \\
$12 / 78$ & General Mining \& Finance & $5: 1$ \\
$12 / 79$ & African Cables & $4: 1$ \\
$2 / 80$ & Dorbyl & $2: 1$ \\
$5 / 80$ & Samancor & $5: 1$ \\
$10 / 80$ & Triomf Fertiliser & $2: 1$ \\
$11 / 80$ & Mathieson \& Ashley & $5: 1$ \\
$11 / 80$ & Investors Club & $4: 1$ \\
$12 / 80$ & Gypsum Industries & $10: 1$ \\
$12 / 80$ & Reunert & $2: 1$ \\
$3 / 81$ & Associated Engineering & $2: 1$ \\
$8 / 81$ & National Selections & $4: 1$ \\
$8 / 81$ & Industrial Selections & $4: 1$ \\
$1 / 82$ & Mercatrust & $5: 1$ \\
$5 / 82$ & Mooi River Textiles & $4: 1$ \\
$7 / 83$ & C.N.A. Gallo & $5: 1$ \\
$10 / 83$ & Gold Fields of S.A. Ltd. & $5: 1$ \\
$11 / 83$ & Grinaker Holdings & $5: 1$ \\
$1 / 84$ & Pretoria Portland Cement & $2: 1$ \\
$6 / 84$ & Hosken Consolidated & $2: 1$ \\
$7 / 84$ & Hartebeestfontein Gold Mining Co. & $10: 1$ \\
$12 / 84$ & Zandpan Gold Mining Co. & $10: 1$ \\
\hline & & \\
& & sho
\end{tabular}

\section{Sample segmentation}

Because the trading values for shares included in the sample were extremely variable and it was thought that well-traded shares may behave differently from poorly traded ones, it was decided to divide the sample into two groups of shares based on traded value.
Trading values on the exchange as a whole fluctuate noticeably from year to year. As the splits making up the sample occurred over a 13-year period, it was necessary to devise an index of value traded against which the annual transaction values of the shares could be compared.

The index was based on 1984 (index $=1,00$ ) and the value of the index for any given year was calculated by dividing the trading value for 1984 by the trading value in that year.

The actual traded value in each share was recorded for three years, namely the year prior to the split, year of the split, and year after the split. Each of these values was then multiplied by the relevant index factor computed above, and the three products added together to obtain a 'three year's indexed' sum. (For the 1984 split events, only two year's data were available. A pro-rata adjustment was made to these values to render them comparable to the rest of the sample).

The 34 shares were then ranked on the basis of the three year's indexed sums. The top 17 shares were grouped together to form a 'high traded value' sample, and the botton 17 likewise into a 'low traded value' sample.

\section{Estimating residuals}

The aim of the study was to isolate the effects which the share split may have had on shareholder returns. Over the 13-year period of the study, general economic and stock market conditions varied tremendously. It was therefore necessary to remove from the data the effect of such changes. A commonly used method is the so-called Market Model (Bowman, 1983: 568), whereby an ordinary least squares regression is employed to estimate the required risk-adjusted returns for the share.

The equation for the model may be written:

$R_{i t}=\hat{a}_{i}+\hat{b}_{i} \tilde{R}_{m t}+\bar{e}_{i t}$,

where $\tilde{R}_{i t}=$ return on security $i$ in period $t ; R_{m t}=$ return on the market portfolio in period $t ; \hat{a}_{i}, \hat{b}_{i}=$ constants for security $i$; and $\overline{e_{i t}}=$ disturbance term or residual.

The parameters of the model are computed using a best fit linear regression. They are then used to calculate the residuals:

$\boldsymbol{e}_{i t}=R_{i t}-\left(\hat{a}_{i}+\hat{b}_{i} \boldsymbol{R}_{m t}\right)$,

for each share, where it is assumed that $E\left(e_{i r}\right)=0$ and $\operatorname{covar}\left(e_{i t}, e_{j r}\right)=0$ for $i$ not equal to $j$.

A portion of the data series is used to estimate the model parameters for each share in the sample. The best fit line for the regression of share returns versus market returns was estimated using the data points for event time months -48 to -15 . The points -14 through +11 were excluded as they surrounded the event. In this region expected non-zero residuals could have caused mis-specification of the best fit line. This was similar to the approach used by Fama, et al. (1969).

The residuals for the 34 shares were then calculated on a monthly basis from month -47 to month +11 . These residuals were aggregated for each event month. Cumulative average residuals were computed for the full sample of 34 shares. In addition, CAR's were separately computed for the two segmented samples, namely the 17 shares within the upper half of traded turnover values, and the 17 shares within the lower half of traded values.

\section{The cusum technique}

This is a powerful technique for studying sequences of figures in order to detect changes in their average levels and determine the point of onset of such changes. In addition to it's use 
in process control, it has wide applicability in 'post-mortem' investigations on historical data (Chatfield, 1978).

The technique was applied to the CAR graphs to pinpoint the months in which changes in the slopes of the graphs occurred. The 'span' method, described by Woodward \& Goldsmith (1964), was used to identify the points of change.

\section{Results}

A study of Table 1 reveals that nine splits occurred during $1973 / 74$, ten during 1980/81 and seven during 1983/84. The JSE actuaries index reached a peak in March 1974, again in October 1980 and April 1984. Thus three quarters of the splits occurred around periods of high general share price levels. This observation is in line with the evidence of, Fama et al. (1969).

The CAR graphs were plotted and the results are shown in Figures 1 and 2.

The CAR graph for the full sample fell continuously from the start (month -47 ) until month -31 . Here a turning point in the curve was observed, and the graph rose continuously until the month of the split event. The graph of necessity passed through the $x$ axis at month -15 , because the period -47 to -15 was used to estimate the parameters.

The average risk-adjusted performance of the 34 shares clearly improved from month -31 and continued to outperform the market until the time of the share split. This above-average performance terminated after month 0 , at which point the slope of the graph changed and a slight decrease in CAR's to month + 11 was observed.

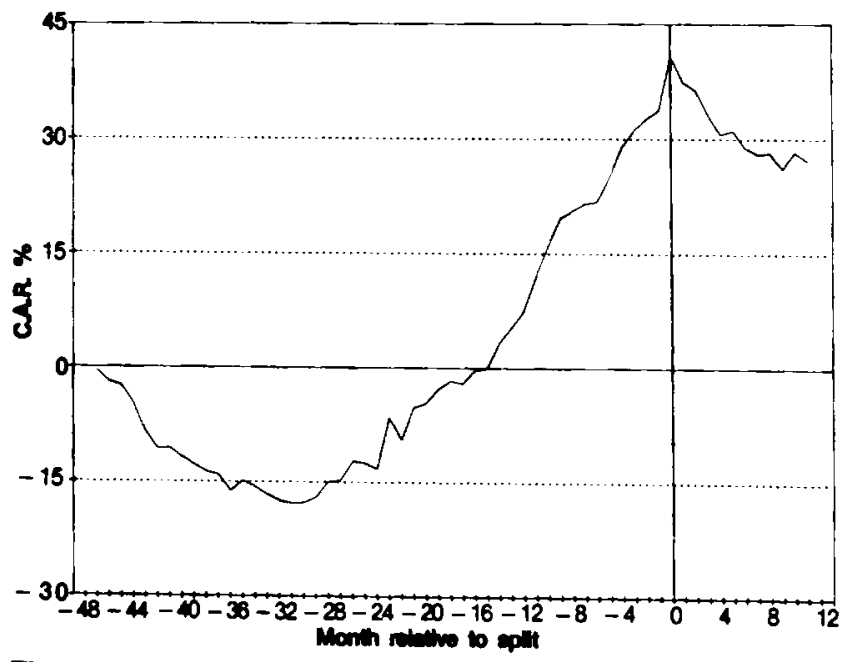

Figure 1 Cumulative average residuals of all 34 shares

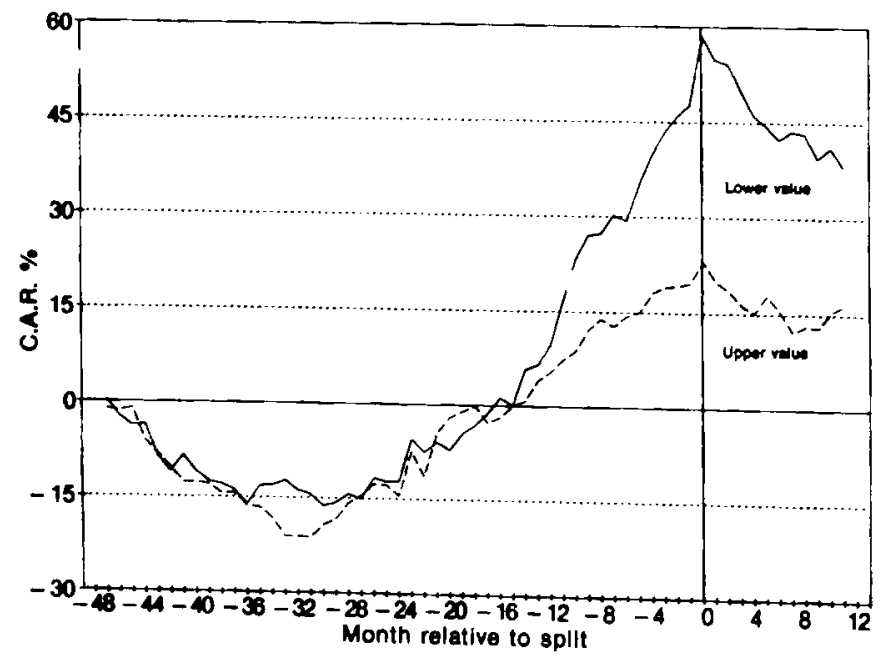

Figure 2 Cumulative average residuals of 17 share portfolios
This finding was conceptually identical to that of Fama, et al. (1969), who found the same pattern of performance in the USA. Rather surprisingly, the turning point at about month -31 corresponded closely to the event time at which Fama, et al. pinpointed the commencement of above average returns.

The excess return in month 0 was over $7 \%$ for the sample of 34 shares. The CAR was of the order of $40 \%$ at month 0 .

The CAR's of the higher and lower halves of the sample, as ranked by relative value traded, showed the same basic pattern of performance as was seen for the 34-share portfolio.

The only significant difference was in the magnitude of the changes, which were clearly different during the months surrounding the event.

The average residuals in the segmented samples for month 0 were $3,4 \%$ and $10,8 \%$ respectively for the high and low traded value segmented samples. The CAR's were $23,1 \%$ and $58,5 \%$.

The performance of the 17 share portfolios was very similar until month -15 . Both portfolios started displaying aboveaverage returns at approximately the same time, i.e. at about month -31 .

After month -15 , however, a divergence in the rate of CAR growth became clearly evident, with the residuals for the lower value portfolio increasing 2,5 times faster than those of the more heavily traded portfolio. After month 0 , this pattern was reversed, with relatively faster declines in the price relatives of the lower value portfolio.

This differential could be interpreted as follows:

(i) Because institutions tend to invest mainly in heavily traded shares to ensure trading liquidity, the high value traded portfolio is likely to have reflected a relative preponderance of institutional investor activity. Conversely, the more thinly traded portfolio is likely to have reflected relatively more individual investor activity.

Consequently, in view of the individual's more favourable view of share splits (NYSE, 1980a), the more thinly traded shares might have been expected to react more positi ely in the period before the split. This could have been due to rumour or expectation of a split, fuelled by recent increases in share price.

After the split event, the CAR graph of the low value traded segment of the sample fell faster than the high value graph. The greater rate of fall may be a consequence of higher unfulfilled investor expectations of increased cash flows, just as the greater rate of increase ahead of the split was the result of anticipated gains.

(ii) The institutional investor is less likely to be affected by rumour or the expectation of splits, because (at least in the USA) they claim to have little interest in splits (NYSE, 1980b). Evidence for this can be found in the fact that the CAR curve for the upper value portfolio was virtually linear from month -31 to the time of the event, whereas that for the lower value curve changed slope and rose much more rapidly in the months before the split event.

The results of applying the cusum technique confirmed that significant changes in the local means of the average residuals occurred at event times $-31,-15$ and 0 . When the technique was applied to the two value-segmented portfolios, it was found that the change identified at time -15 was only confirmed for the lower value portfolio.

\section{Post-split price ranges}

One of the stated objectives of companies that split their shares is the achievement of a more 'popular' price range (NYSE, 1980c). 
Table 2 Post-split share prices

\begin{tabular}{cc}
\hline Price range (in cents) & No of shares \\
\hline$<300$ & 19 \\
$300-499$ & 8 \\
$500-699$ & 3 \\
$>700$ & 4 \\
\hline
\end{tabular}

Post-split prices of the shares in this study were grouped to ascertain the most common price ranges selected for the shares post split. The results are shown in Table 2.

Clearly, most companies selected a split ratio to achieve a price of less than $300 \mathrm{c}$ per share and almost $80 \%$ chose a price of less than $500 \mathrm{c}$.

The majority of splitting companies therefore seem to believe that for a share to trade in a popular price range, its price should be below $500 \mathrm{c}$. Naturally management would expect to observe an increase in their share price over time, and would therefore set a split ratio that would drop their share price well into the 'popular' trading range, rather than near its top.

It should be noted, however, that because inflation was present at high levels for some years during the long period over which the events occurred, grouping share prices into intervals may be somewhat misleading.

\section{Changes in value traded}

In order to rank the shares for sample segmentation purposes, traded values had been standardized to account for differences in overall trading levels in the different years. These data were used to investigate whether or not the split events themselves had caused any significant changes in the Rand value of shares traded.

The examination took the form of a test of the difference between the mean traded values in the years before and after the split. The shares which split in 1984 were excluded because the post-split year's values were not yet available.

The null hypothesis used was that there was no difference in trading value before and after the split and therefore means were equal. It was examined using a $t$ test on the distribution of differences in indexed traded values for the years on either side of the year of the split. It was found that the null hypothesis could not be rejected at the $5 \%$ level of significance.

The test was repeated for comparisons of the pre-split year with the split year, and for the split year and post-split year. No significant differences were found here either.

Separate tests of traded value means for the upper and lower value segments of the sample were also carried out. As with the larger sample, no significant differences in means were found for the three sets of comparisons tested.

It can therefore be concluded that the value of trading in a share is not affected by a share split. However, because the unit value of a share decreases after a split, this implied an increase in the number of shares traded. Of interest would be a study of the actual number of trades done in a given time period before and after the split, as well as a study of split-adjusted volume of shares traded on either side of the event date. These did not, however, form part of the scope of the present study.

\section{The costs of a share split}

The costs of a share split proved difficult to ascertain with any degree of accuracy. Six companies that had split their shares in the last few years were approached for cost details.
None had specifically kept track of the cost though they did volunteer the estimated direct costs for expenses such as printing, postage, registered mail, computer time, and advertising to be of the order of R40,000. Indirect costs, which include staff man-hours and other overheads, were not quantified but were felt to be extensive.

Cost estimates varied mainly in proportion to the number of shareholders in a company, as well as being dependent on whether the split was an independent event, or whether the requisite general meeting was held simultaneously with another meeting such as the Annual General Meeting, thus leading to savings in postages, printing, etc.

On the whole, the costs involved in a share split appear to be quite significant, especially when viewed against the background of the academic literature, which shows no benefits to shareholders for the expense incurred.

\section{Conclusions}

Although only a relatively small number of splits occurred in the period studied, their timing seems to indicate that split activity increases on the JSE when the market is in a boom period.

In line with the findings of prior research in the USA, it appears that share splits have no lasting, long-term, favourable effect on share prices.

Splits appeared to be a reaction to a sustained period of above-average returns, rather than being the cause of such returns. Remarkably similar performance patterns of the residuals were found in this study and in the study of Fama, et al. (1969). In both cases the above-average returns terminated immediately after the split event.

Owing to the one-month intervals used in this study, no reliable conclusions could be reached about the possibility of short-term benefits available to traders. It seems likely that even greater short-term effects might have been found to exist if daily prices were examined, as was found by Reilly \& Drzycimski (1981). The large average residual return of $10,8 \%$ that occurred during month 0 in the lower value portfolio strongly suggests the likelihood of a short-term profit opportunity during that period.

It is clear from the graphs that abnormal returns cannot be expected by purchasing shares after the split has become effective. Fama, et al. (1969), when drawing the same conclusion, noted that their study had revealed that no abnormal returns could be made by buying after the announcement date.

In order to be able to take trading advantage of the increase in CAR's found in this study, investors need to be able to decide correctly which companies are in fact going to split their shares. Even then not all shares will in fact show positive residuals in the chosen holding period, for individual residuals are distributed about zero, and in each of the pre-split months studied, a number of the individual shares' residuals were negative.

Although Copeland (1979) found evidence of reduced trading liquidity after splits, in this study no significant changes were found in trading values in the years surrounding the split.

The results of this study appear to support prior research findings overseas and indicate that there seem to be no longterm economic gains to be obtained from a share split.

In the face of these negative findings, South African financial managers should seriously question what potential benefits can be expected to justify the expense of split. A type of clientele effect could be operative here. Companies seeking a larger spread of small investors would opt for 
splitting, whereas those to whom a spread of ownership is undesirable (for example if a merger is a possibility) would not split.

Effort and cost could be expended more productively in the development of cheaper 'odd-lot' trading mechanisms for the benefit of the smaller investor. This would have the effect of allocating the cost of such facilities to the persons using them, rather than burdening companies with share-splitting expenses which do not benefit their biggest investing public - the institutions.

\section{References}

Barker, C.A. 1956. Effective Stock Splits. Harv. Bus. Rev., vol.34(1), 72-79.

Bowman, Robert G. 1983. Understanding and Conducting Event Studies. J. Bus. Fin. Account, vol.10(4), $561-584$.

Chatfield, C. 1978. Statistics for Technology $-A$ course in Applied Statistics. 2nd Edition. London: Chapman and Hall.
Copeland, T.E. 1979. Liquidity Changes Following Stock Splits. J. Fin., vol.34(1), 115-141.

Fama, E.F., Fisher L., Jensen M.C. \& Roll, R. 1969. The Adjustment of Stock Prices to New Information. Intern. Econ. Rev., vol.10(1), 1-21.

Grinblatt, M.S., Masulis, R.W. \& Titman, S. 1984. The Valuation Effects of Stock Splits and Stock Dividends. J. Fin. Econ., vol.19, $461-490$.

Murray, D. 1985. Further Evidence on the Liquidity Effects of Stock Splits and Stock Dividends. J. Fin. Res., vol.8(1), $59-67$.

New York Stock Eschange 1980a. Individual Investors' Attitudes Towards Stock Splits. Business Research Department, NYSE.

New York Stock Exchange 1980b. Institutional Investors' Attitudes Towards Stock Splits. Business Research Department, NYSE.

New York Stock Exchange 1980c. Corporate Attitudes Towards Stock Splits. Business Research Department, NYSE.

Reilly, F.K. \& Drzycimski, E.F. 1981. Short-run Profits from Stock Splits. Fin. Manage., vol.10(2), 64-74.

Woodward, R.H. \& Goldsmith, P.L. 1964. Cumulative Sum Techniques. Edinburgh: Oliver and Boyd. 